\title{
Potential of Some Granites from Foumban (West Region of Cameroon) as Fluxing Materials for Ceramics
}

\author{
Njimbouombouo Mouliom Soualiou, Etone Macka Alexandre Dodo, \\ Ondoua Abondo Ebengue Yannick, Che Randy Nangah, Njoya André, \\ Mouncherou Oumar Farouk, Ndigui Billong
}

University of Yaounde I, Yaounde, Cameroon

Email: njimbouombouomouliom@yahoo.fr

How to cite this paper: Soualiou, N.M., Dodo, E.M.A., Yannick, O.A.E., Nangah, C.R., André, N., Farouk, M.O. and Billong, N. (2020) Potential of Some Granites from Foumban (West Region of Cameroon) as Fluxing Materials for Ceramics. Journal of Minerals and Materials Characterization and Engineering, 8, 353-363.

https://doi.org/10.4236/jmmce.2020.85022

Received: July 15, 2020

Accepted: August 4, 2020

Published: August 7, 2020

Copyright $\odot 2020$ by author(s) and Scientific Research Publishing Inc. This work is licensed under the Creative Commons Attribution International License (CC BY 4.0).

http://creativecommons.org/licenses/by/4.0/ (c) (i) Open Access

\begin{abstract}
This study focuses on the mineralogical, geochemical and petrographic characterization of three granite rock samples (LTP, LTS and LTMB) from Foumban, West Region of Cameroon. Fusibility tests were carried out on the samples containing the highest amount of alkali to assess the potential of these materials as fluxing admixture for ceramics. The results show that the granite consists of alkaline feldspars, notably orthoclase and microcline of perthitic micro-texture, plagioclases (in particular albite) and also mafic minerals such as amphibole and pyroxene. The quantity of alkali in the samples is quite high (16.83\% for LTS, $17.08 \%$ for LTMB and $18.87 \%$ for LTP) compared to standard data. Fusibility tests carried out on the samples having the highest alkali content (LTMB and LTP) showed that the vitreous phase appears between $1050^{\circ} \mathrm{C}$ and $1100^{\circ} \mathrm{C}$ in these samples when they were heated. The $\mathrm{Fe}_{2} \mathrm{O}_{3}$ and $\mathrm{TiO}_{2}$ content of LTMB (3.01\% and $1.49 \%$ respectively) led to a brown colour of its fired product. Therefore, based on their composition, these materials can be used as feldspathic fluxes for the formulation of ceramic products.
\end{abstract}

\section{Keywords}

Feldspars, Granite, Characterization, Fusibility, Ceramics, Foumban, Cameroon

\section{Introduction}

Nowadays, feldspathic minerals are more and more and more sought after be- 
cause of the important role they play in the traditional ceramic industry. These minerals are common in rocks and have found several applications in different industries [1]. Feldspathic fluxes can be used in a wide range of ceramic products such as in wall tiles, floor tiles, sanitary ware and glasses [2]. They play the role of degreaser during the firing of shards of glass on the one hand and on the other hand, because of their chemical compositions (rich in $\mathrm{K}_{2} \mathrm{O}$ and $\mathrm{Na}_{2} \mathrm{O}$ ) promote the formation of a vitreous phase at lower melting temperatures [3]. Consequently, the firing temperature of clay formulations containing a given proportion of feldspathic fluxes is considerably reduced, resulting in an energy gain.

The world today faces the challenge of a high decrease in the supply of feldspar from its main mineral deposits making it essential to find alternative sources of feldspar which is the second component of ceramic pastes [4]. In Cameroon, very little work has been carried out to identify the sources of feldspathic materials that can be used in ceramic formulations. Research in this area has been those of a few authors, carried out on the syenite of Lala, nepheline syenites of Kribi and pegmatite of Penja [5] [6] [7], and on the Dschang feldspar mineral deposit [8]. These authors concluded that these deposits can be exploited as potential sources of feldspar fluxes for applications in the ceramic and glass industry. Granitoids, pegmatites, aplites, alkaline and nepheline syenites are the main known sources of feldspar worldwide. The main sources of these rocks are given in Table 1. Among granitoids, granite constitutes an important source of feldspar [2]; granite exploitation opens up a field of research due to its abundance.

The rocky bedrock of Foumban (West Region of Cameroon) consists of volcanic rocks which, as a result of weathering have led to the establishment of several clay deposits [9] [10] [11] and of crystalline rocks such as mylonite, gneiss and granites which make up the Mayouom kaolin deposits [12]. The presence of these clay deposits in the area could favour the development of the ceramic industry. However, little work has been done to determine the feldspar content of granite rocks from Foumban and their possible use as fluxing materials for ceramics. The aim of this work is to characterise the mineralogical, geochemical, petrographic properties of some granites from Foumban and to study their high temperature properties for their application in ceramic formulations.

\section{Experimental}

\subsection{Sampling}

The three samples (LTP, LTS and LTMB) studied in this work were collected from Foumban, in locations where the main crystalline rock base lies. The samples were taken from syntectonic granites, which are very rich in alkali feldspar phenocrysts and poor in mafic minerals. These rocks consist of perthitic microcline, plagioclases including albite and ferromagnesian biotite and amphibole minerals [13]. Figure 1 shows geological map of the sample collection site located in Foumban (West Region of Cameroon). 


\subsection{Characterization}

For mineralogical and geochemical analysis, the rock samples were crushed to 1 - $5 \mathrm{~cm}$ diameter using a hammer, ground in a ball mill and sieved with a $100 \mu \mathrm{m}$ sieve. Thin sections were prepared for petrographic analysis.

Table 1. Main sources of feldspathic raw materials generally used in ceramic formulation (modified after Dondi et al. [2]).

\begin{tabular}{|c|c|c|c|}
\hline Source & Code & Description & Deposit example \\
\hline Granitoids & GRA & $\begin{array}{l}\text { Coarse-grained plutonic rocks, rich in feldspars and } \\
\text { oversaturated in silica (quartz }>20 \% \text { ). Fluxes are } \\
\text { mainly recovered from granites (particularly } \\
\text { leuco-granites) with minor granodiorites, } \\
\text { alkaligranites, and some trondhjemites. }\end{array}$ & $\begin{array}{l}\text { Spruce pine, USA; } \\
\text { Montebras, France; } \\
\text { Strzeblow, Poland. }\end{array}$ \\
\hline Pegmatites & PEG & $\begin{array}{l}\text { Very coarse-grained basement rocks, abundant in } \\
\text { feldspar, which in most cases are acid differentiates } \\
\text { of granitoids (or syenoids). Fluxes come from all } \\
\text { subtypes: plutonic pegmatites, pseudo-pegmatites, } \\
\text { meta-pegmatites and pegmatoids. }\end{array}$ & $\begin{array}{l}\text { Sierras pampeanas, } \\
\text { Argentina; Black } \\
\text { Hills, USA; } \\
\text { Kyrkoberget Finland. }\end{array}$ \\
\hline Aplites & APL & $\begin{array}{l}\text { Differentiates of granitoid (or syenoid) rocks with a } \\
\text { fine-grained texture. Some fluxes are commercialised } \\
\text { as "aplites", as they exhibit an (apparent) aplitic } \\
\text { texture, e.g. due to rock alteration. }\end{array}$ & $\begin{array}{l}\text { Botro ai Marmi, } \\
\text { Italy; Shigaraki, } \\
\text { Japan; Montpelier, } \\
\text { USA. }\end{array}$ \\
\hline $\begin{array}{l}\text { Acid } \\
\text { volcanics } \\
\text { and } \\
\text { subvolcanis }\end{array}$ & RHY & $\begin{array}{l}\text { Extrusive acid rocks (rhyolite, rhyodacite, dacite, } \\
\text { comendite) including subvolcanic and hypabyssal } \\
\text { types (porphyry). Fluxes are recovered from lavas, } \\
\text { domes, pyroclastics (cinerite, tuff, ignimbrite, and } \\
\text { perlite) and veins. }\end{array}$ & $\begin{array}{l}\text { Ahuazotepec, Mexico; } \\
\text { Lozzolo, Italy; } \\
\text { Türkismühle, } \\
\text { Germany. }\end{array}$ \\
\hline $\begin{array}{l}\text { Nepheline } \\
\text { syenites } \\
\text { and } \\
\text { phonolites }\end{array}$ & NSP & $\begin{array}{l}\text { Silica-undersaturated rocks containing feldspars and } \\
\text { feldspathoids (nepheline, leucite, etc.). Fluxes are } \\
\text { typically obtained as nepheline syenite or its extrusive } \\
\text { equivalent nepheline phonolite, but also ultrapotassic } \\
\text { rocks can be utilized. }\end{array}$ & $\begin{array}{l}\text { Blue Mountain, } \\
\text { Canada; Stjernoy, } \\
\text { Norway; Lages, } \\
\text { Brazil. }\end{array}$ \\
\hline $\begin{array}{l}\text { Feldspathics } \\
\text { arenites }\end{array}$ & ARK & $\begin{array}{l}\text { Feldspathic sandstones and conglomerates (and the } \\
\text { corresponding unlithified sediments). Fluxes are } \\
\text { mostly recovered from arkoses and subarkoses, with } \\
\text { some lithic arkoses as well. }\end{array}$ & $\begin{array}{l}\text { Florinas, Italy; } \\
\text { Carrascal del Río, } \\
\text { Spain; Hirschau, } \\
\text { Germany. }\end{array}$ \\
\hline Metamorphics & MET & $\begin{array}{l}\text { Metamorphic equivalents of previous deposits (e.g. } \\
\text { gneiss, porphyroid, micaschist, quartzite) mostly in } \\
\text { the greenschist facies. Fluxes are mainly obtained } \\
\text { from phyllites and gneisses. }\end{array}$ & $\begin{array}{l}\text { Itapeva, Brazil; } \\
\text { Campo Largo, Brazil; } \\
\text { Robilante, Italy. }\end{array}$ \\
\hline Albitites & ALB & $\begin{array}{l}\text { Metasomatic rocks formed through an albitization } \\
\text { process that leads to the formation of almost } \\
\text { monomineralic bodies (albite after plagioclase and } \\
\text { K-feldspar) under the action of metamorphic fluids. }\end{array}$ & $\begin{array}{l}\text { Menderes, Turkey; } \\
\text { Ottana, Italy; } \\
\text { Salvezines, France. }\end{array}$ \\
\hline $\begin{array}{l}\text { Epithermal } \\
\text { alterations }\end{array}$ & EPI & $\begin{array}{l}\text { Hydrothermal alteration giving rise to peculiar rock } \\
\text { types: porcelain stone, eurite, agalmatolite, pinite, } \\
\text { toseki and roseki (in Japanese), dunzi or baidunzi (in } \\
\text { Chinese) including episyenite and sanidinite. }\end{array}$ & $\begin{array}{l}\text { Amakusa, Japan; } \\
\text { Crocetta, Italy; Gusev, } \\
\text { Russia. }\end{array}$ \\
\hline $\begin{array}{l}\text { Alternatives } \\
\text { sources }\end{array}$ & & $\begin{array}{l}\text { Low-melting minerals alternative to feldspars; } \\
\text { end-of-life materials and byproducts, typically } \\
\text { feldspar bearing or largely glassy, such as mining } \\
\text { residues, waste glasses, and combustion ashes. }\end{array}$ & \\
\hline
\end{tabular}




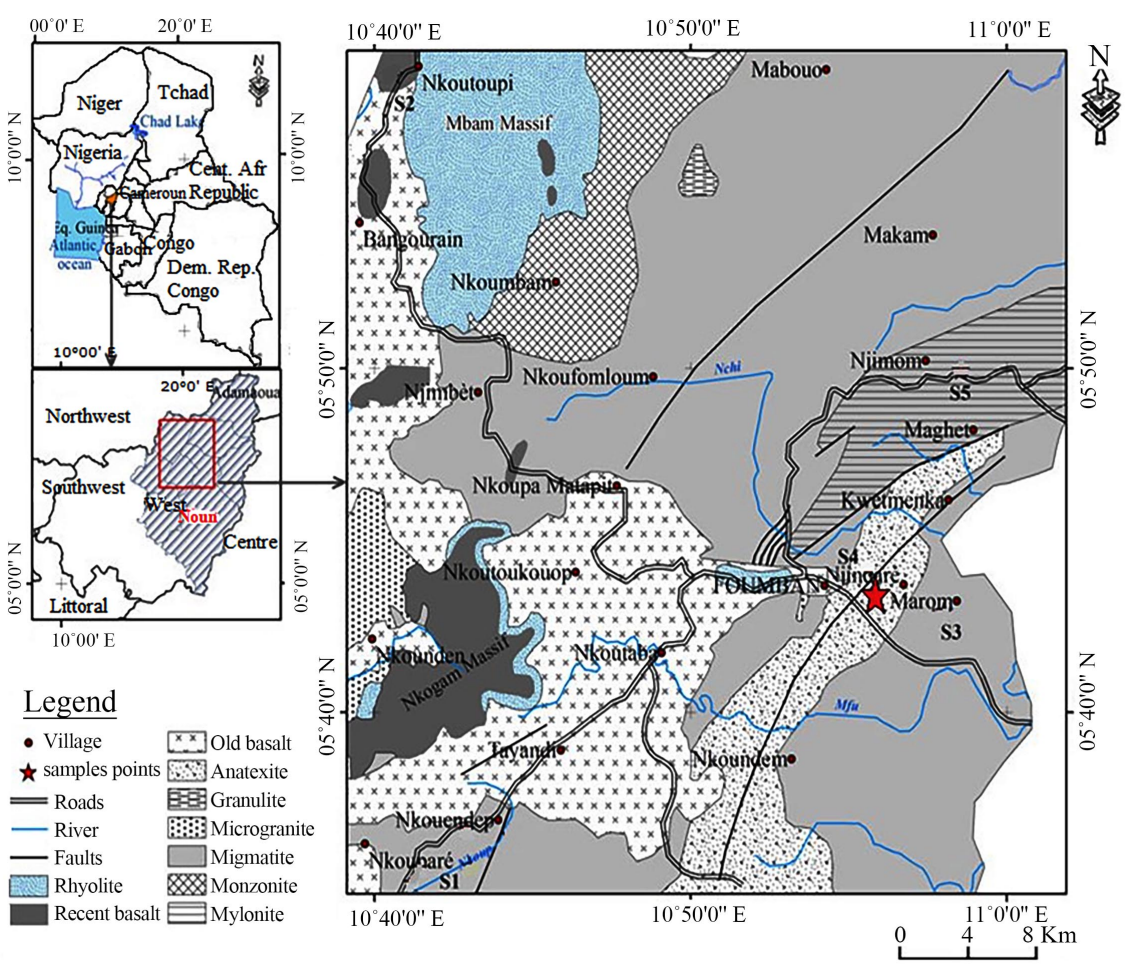

Figure 1. Geological map of the locality of Foumban showing the locations of the mineral deposits (modified after Mefire et al. [11]).

\section{- Mineralogical analysis}

To determine the mineralogical phases, X-ray diffraction was carried out using a Bruker D8 Advance diffractometer. The spectra were recorded from $2^{\circ}$ to $70^{\circ}$ with CuKa radiation, no spin, wavelength $\mathrm{ka}=1.5406 \AA$, and a scan rate of $0.020^{\circ}$, operating at $40 \mathrm{KV}$ and $25 \mathrm{~mA}$ at the Clay, Geochemistry and Sedimentary Environment Laboratory, University of Liège. The mineralogical composition was obtained by analysing the diffractograms using the HighScore Plus software.

- Geochemical analysis

Geochemical analysis was performed to determine the major iron oxides in each sample using an ARL 9400 Sequential X-ray fluorescence spectrometer at the Petrology, Geochemistry and Petrophysics Laboratory, University of Liège. The samples $(0.34 \mathrm{mg})$ were calcined at $100^{\circ} \mathrm{C}$ and mixed with $\mathrm{KBr}(3.74 \mathrm{mg})$ and $\mathrm{LiBr}(0.0002 \mathrm{mg})$; the mixture was heated then poured into pearl-shaped moulds and let to cool for 5 mins before analysis.

\section{- Petrography}

Petrography was carried out by observing thin sections of the granite rock sample under a polarizing microscope at the Department of Earth Sciences, University of Yaoundé I.

- Thermal analysis and fusibility tests

Fusibility test to determine melting temperature, change in morphology and viscosity was carried out by heating the powders in a Nabertherm oven, model 
LH 60/40 at the Laboratory of Physico-chemistry of Mineral Materials, University of Yaoundé I. $5 \mathrm{~g}$ of each powder sample was shaped into a cone using an XZ 843 refractory glue as a binder. A good feldspathic flux maintains its white colour when fired and is one for which the vitreous phase appears between $1140^{\circ} \mathrm{C}$ and $1280^{\circ} \mathrm{C}$ [14]. Therefore, to determine temperature at which fusion and the vitreous phase occurs, firing was done at $1050^{\circ} \mathrm{C}, 1100^{\circ} \mathrm{C}$ and $1200^{\circ} \mathrm{C}$. Figure 2 illustrates the heating profile of the cones. The cones were heated in a furnace from $25^{\circ} \mathrm{C}\left(\mathrm{T}^{\circ}{ }_{1}\right)$ to $300^{\circ} \mathrm{C}\left(\mathrm{T}^{\circ}{ }_{2}\right)$ at a heating rate of $5^{\circ} / \mathrm{h}$ for $60 \mathrm{mins}$, and from $300^{\circ} \mathrm{C}$ to $1200^{\circ} \mathrm{C}\left(\mathrm{T}_{3}^{\circ}\right)$ at a heating rate of $5^{\circ} \mathrm{C} / \mathrm{h}$ for 180 mins. A holding time of 120 mins was then applied to the samples before cooling for a period of 3 days. At the end of the heat treatment, the texture and shape of the cones will provide information on the fusibility of the material. The change in colour of the products was deduced from the Munsell code [15].

\section{Results and Discussion}

\subsection{Mineralogy}

The X-ray diffraction patterns of the studied samples are given in Figure 3. The main diffraction peaks are those of alkaline feldspars (orthosis, microcline), plagioclase (albite) and biotite. The secondary peaks are those of amphibole and pyroxene. These are common minerals found in feldspathic fluxes that are used in ceramic formulations [16] [17]. However, the presence of ferromagnesian minerals such as biotite, pyroxene and amphibole could impart a dull tone in the product after firing [18], likewise the presence of plagioclases could delay the appearance of the glassy phase [5]. Thus, treatment of these materials, in particular samples LTMB and LTS, should be considered before use in ceramic formulations. The presence of quartz confirms the plutonic nature of the granite rocks.

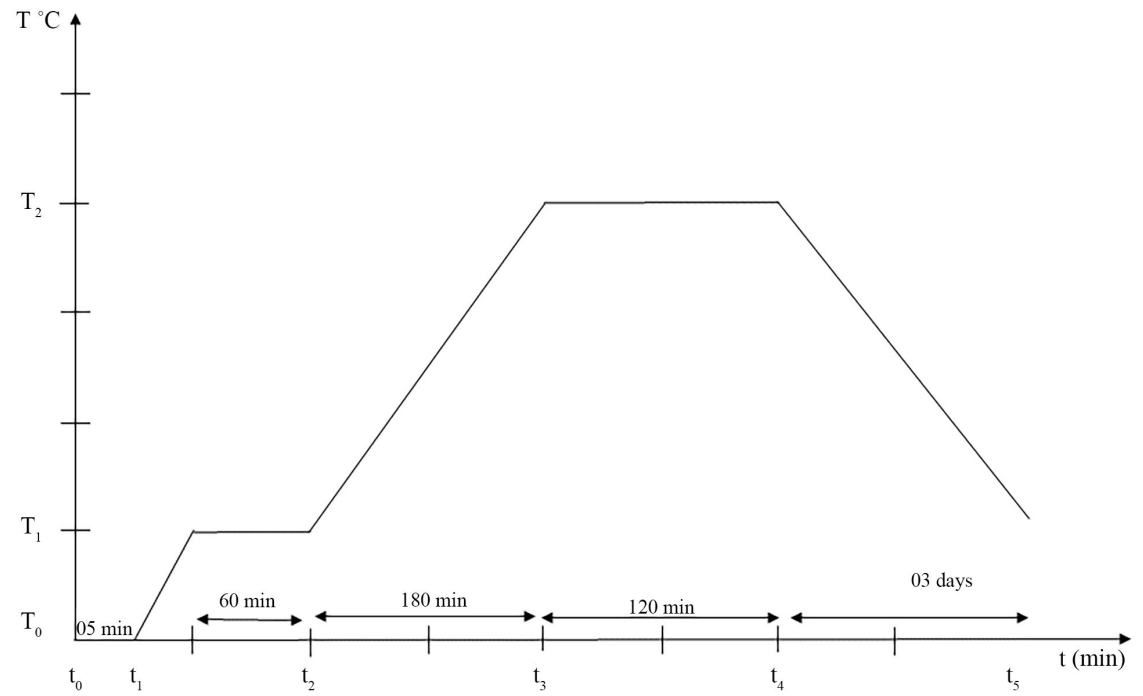

Figure 2. Heating curve, where $\mathrm{T}_{0}^{\circ}$ is the temperature at $25^{\circ} \mathrm{C}, \mathrm{T}^{\circ}{ }_{1}$ is the temperature at $300^{\circ} \mathrm{C}, \mathrm{T}_{2}^{\circ}$ is the temperature at $1200^{\circ} \mathrm{C}$. 


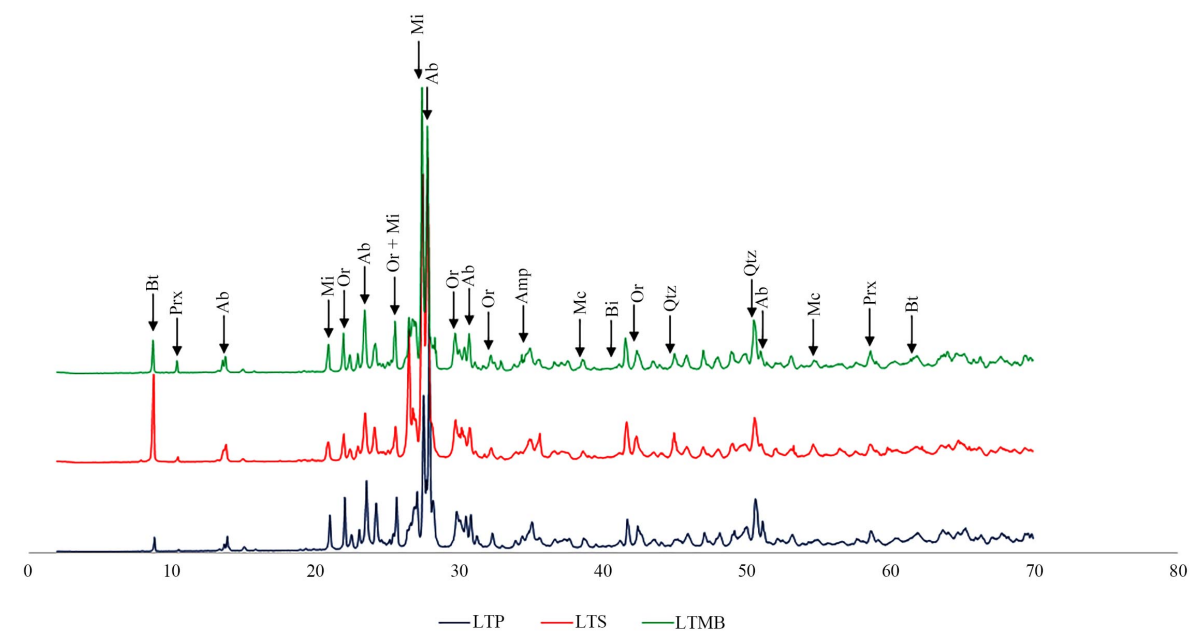

Figure 3. X-ray diffractogram patterns of samples LTP, LTS and LTMB (where, Mi = Microcline; Or = Orthoclase; $\mathrm{Ab}=$ Albite; $\mathrm{Qtz}=$ Quartz; Bt = Biotite; $\mathrm{Mc}=$ Muscovite; $\mathrm{Pyx}$ = Pyroxene; Amp = Amphibole).

\subsection{Geochemistry}

Table 2 presents the major oxides in each feldspathic sample as obtained through $\mathrm{XRF}$ analysis. The results show that the percentage of alkaline oxides $\left(\mathrm{Na}_{2} \mathrm{O} / \mathrm{K}_{2} \mathrm{O}\right)$ in all the sample is quite large at $14.97 \%$ for LTP, $14.18 \%$ for LTS and $14.8 \%$ for LTMB, making them suitable for use as ceramic fluxes [19] [20]. With a minimum content of $16 \%$, the $\mathrm{Al}_{2} \mathrm{O}_{3}$ content for three samples $(18.87 \%$ for LTP, $16.83 \%$ for LTS and $17.08 \%$ for LTMB) is also considered to be high as defined by the Pouliquen standard factsheet for feldspars [17]. The $\mathrm{Fe}_{2} \mathrm{O}_{3}$ and $\mathrm{TiO}_{2}$ contents of the three samples (between $0.3 \%$ and $3.5 \%$ ) are however high [18] and will impart a dull colour on the material when fired. Therefore, purification of the material through magnetic separation followed by enrichment through flotation should be considered if the colour of the end product is to be white [21] [22]. Additionally, the mass of $\mathrm{K}_{2} \mathrm{O}$ and the $\mathrm{K}_{2} \mathrm{O} / \mathrm{Na}_{2} \mathrm{O}$ ratio are very close, which justifies the appearance of a glassy phase during firing [5].

\subsection{Petrography}

The results of the optical microscopic examinations of the thin sections are given in Figure 4. From observation, the rock consists of quartz crystals (3\% to 5\% modal), alkaline feldspar ( $80 \%$ to $85 \%$ modal), mafic ( $5 \%$ to $10 \%$ modal) and accessory minerals such as apatite and sphene. The dominant alkaline feldspar is orthoclase with spark-like perthites (albite) extending up to $8 \mathrm{~mm}$ in length (Figure 4A, Figure 4F and Figure 4B). Some K feldspar crystals show Carlsbad twinning (Figure $4 \mathrm{C}$ ). In some thin sections, we notice the presence of plagioclase feldspars (Figure 4D). Biotite has started transforming to chloride because the rock has undergone some form of weathering (Figure $4 \mathrm{E}$ ). We also note a biotite-amphibole association in Figure 4A and Figure 4B. The mafic minerals (pyroxene, biotite) are interstitially grouped between the feldspar phenocrysts. 
The opaque minerals are amongst the $\mathrm{K}$ feldspars and the hypidiomorphic quartz is interstitial. The rock has a granular porphyroid micro-texture.

Table 2. Major oxides in the studied materials as obtained through XRF analysis (LOI = Loss on Ignition).

\begin{tabular}{cccc}
\hline Oxides & LTP & LTS & LTMB \\
\hline $\mathrm{SiO}_{2}$ & 62.12 & 60.6 & 60.21 \\
$\mathrm{TiO}_{2}$ & 0.38 & 0.81 & 1.49 \\
$\mathrm{Al}_{2} \mathrm{O}_{3}$ & 18.87 & 16.83 & 17.08 \\
$\mathrm{Fe}_{2} \mathrm{O}_{3}$ & 1.16 & 3.55 & 3.01 \\
$\mathrm{MnO}$ & 0.02 & 0.05 & 0.04 \\
$\mathrm{MgO}$ & 0.35 & 2.15 & 1.21 \\
$\mathrm{CaO}$ & 0.78 & 2.03 & 2.02 \\
$\mathrm{Na}$ & 5.9 & 5.55 & 6 \\
$\mathrm{~K}_{2} \mathrm{O}$ & 9.07 & 8.63 & 8.8 \\
$\mathrm{P}_{2} \mathrm{O}_{5}$ & 0.09 & 0.35 & 0.35 \\
$\mathrm{SO}_{3}$ & 0.71 & 0.54 & 0.47 \\
$\mathrm{LOI}$ & 0.71 & 0.54 & 0.47 \\
$\mathrm{Total}$ & 99.46 & 100.1 & 100.69 \\
\hline
\end{tabular}
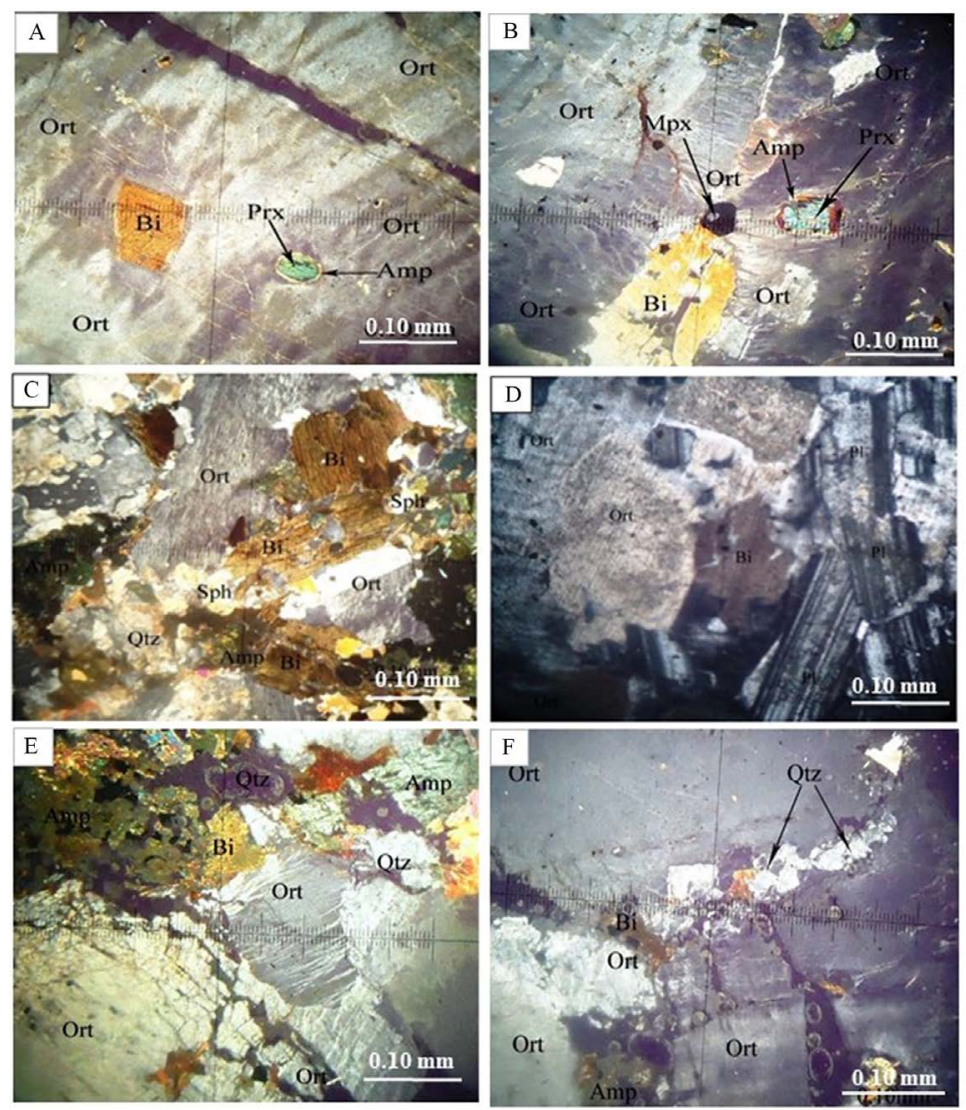

Figure 4. Micrographs of thin sections of granite rock samples from Foumban showing the different minerals present (where, PI = Plagioclases, Qtz = Quartz, $\mathrm{Bt}=$ Biotite, $\mathrm{Amp}=$ Amphibole Prx $=$ Pyroxene, and $\mathrm{Sph}=$ Sphene $)$. 


\subsection{Heat Treatment}

The thermal behaviour of the materials is illustrated in Figure 4 and Table 3. From the figure, the physical changes that occur in the felspars as the temperature rises from $1050^{\circ} \mathrm{C}$ to $1200^{\circ} \mathrm{C}$ can be seen.

From the results of the fusibility test illustrated in Figure 5, Table 3 presents a summary of the texture and colour of the granite cones before and after heat treatment at given temperatures.

For sample LTMB, the brown particle cone is compact, friable between $25^{\circ} \mathrm{C}$ and $1050^{\circ} \mathrm{C}$ (Figure $5 \mathrm{E}$ and Figure $5 \mathrm{~F}$ ). At $1050^{\circ} \mathrm{C}$, the particle cone is a cluster of light brown grains, slightly compact and adheres slightly to the touch (Figure $4 \mathrm{~F}$ ). Between $1100^{\circ} \mathrm{C}$ and $1200^{\circ} \mathrm{C}$, the particle cone is completely glassy and dark brown in colour. The cone becomes a compact reflective block and completely flattened (Figure $4 \mathrm{G}$ and Figure $5 \mathrm{H}$ ).

Table 3. Thermal behaviour of the fired cones at different temperatures.

\begin{tabular}{|c|c|c|c|c|c|c|}
\hline \multirow{2}{*}{$\begin{array}{c}\text { Sample } \\
\text { Temperature }\end{array}$} & \multicolumn{3}{|c|}{ LTMB } & \multicolumn{3}{|c|}{ LTP } \\
\hline & $\begin{array}{c}\text { Munsell } \\
\text { code }\end{array}$ & $\begin{array}{l}\text { Visual } \\
\text { code }\end{array}$ & $\begin{array}{l}\text { Cone } \\
\text { texture }\end{array}$ & $\begin{array}{l}\text { Munsell } \\
\text { code }\end{array}$ & $\begin{array}{l}\text { Visual } \\
\text { code }\end{array}$ & Cone texture \\
\hline $25^{\circ} \mathrm{C}$ & $2.5 \mathrm{Y} 7 / 1$ & $\begin{array}{l}\text { Light } \\
\text { grey }\end{array}$ & $\begin{array}{l}\text { Cone of fine } \\
\text { particles adhering to } \\
\text { the touch }\end{array}$ & $2.5 \mathrm{Y} 8 / 1$ & White & $\begin{array}{c}\text { Cone of fine } \\
\text { particles adhering } \\
\text { to the touch }\end{array}$ \\
\hline $1050^{\circ} \mathrm{C}$ & 10R 6/4 & Pinkish & $\begin{array}{c}\text { Granular particle } \\
\text { cone adherent to the } \\
\text { touch }\end{array}$ & 7.5 YR $8 / 2$ & White & $\begin{array}{c}\text { Cone of fine } \\
\text { particles adhering } \\
\text { to the touch }\end{array}$ \\
\hline $1100^{\circ} \mathrm{C}$ & $\begin{array}{c}2.5 \mathrm{YR} \\
2.5 / 3\end{array}$ & Brown & $\begin{array}{c}\text { Compact glassy } \\
\text { block that spreads } \\
\text { over the base }\end{array}$ & $2.5 Y 8 / 1$ & White & $\begin{array}{l}\text { Cone of fine } \\
\text { particles, not } \\
\text { adhering to the } \\
\text { touch }\end{array}$ \\
\hline $1200^{\circ} \mathrm{C}$ & $\begin{array}{c}7.5 \mathrm{YR} \\
2.5 / 1\end{array}$ & $\begin{array}{c}\text { Dark } \\
\text { brown }\end{array}$ & $\begin{array}{c}\text { Compact glassy } \\
\text { block that spreads } \\
\text { over the base }\end{array}$ & 5YR 8/1 & White & $\begin{array}{l}\text { Cone of fine } \\
\text { particles, not } \\
\text { adhering to the } \\
\text { touch }\end{array}$ \\
\hline
\end{tabular}
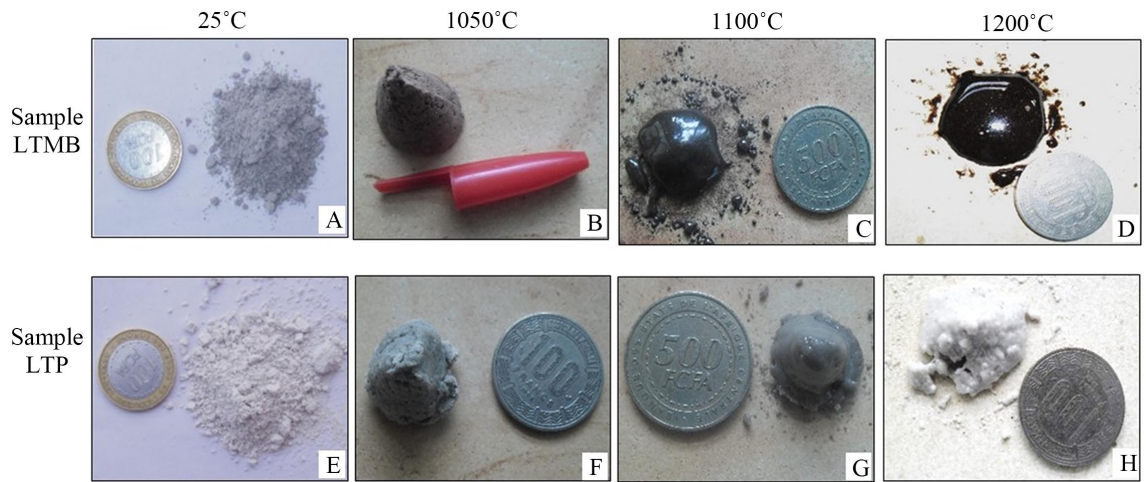

Figure 5. Effect of heating on the cone shaped feldspars from Foumban (where, $\mathrm{A}=$ temperature at $25^{\circ} \mathrm{C} ; \mathrm{B}=$ temperature at $1050^{\circ} \mathrm{C} ; \mathrm{C}=$ temperature at $1100^{\circ} \mathrm{C}$ and $\mathrm{D}=$ temperature at $1200^{\circ} \mathrm{C}$ for $\mathrm{LTMB}$ and $\mathrm{E}=$ temperature at $25^{\circ} \mathrm{C} ; \mathrm{F}=$ temperature at $1050^{\circ} \mathrm{C} ; \mathrm{G}=$ temperature at $1100^{\circ} \mathrm{C}$ and $\mathrm{H}=$ temperature at $1200^{\circ} \mathrm{C}$ for LTP). 
In the case of sample LTP, it appears white at $25^{\circ} \mathrm{C}$ and at $1050^{\circ} \mathrm{C}$ (Figure $5 \mathrm{~A}$ and Figure 5B); the colour of the cone of fine particles adheres to touch, remains white and compact. At $1100^{\circ} \mathrm{C}$, the base of the cone starts deforming with an increase in its diameter (Figure $5 \mathrm{C}$ ). The cone compacts into a glassy reflecting white-coloured block and it no longer adheres to touch. Above $1100^{\circ} \mathrm{C}$, the vitreous phase appears completely, the cone of fine particles remains white, reflecting and does not adhere to touch. The base of the cone is totally flattened (Figure 5D).

The result from the fusibility tests show that the high fusibility and white colour of sample LTP is due to its mineralogical composition (essentially feldspar and very few mafic minerals). Thus, at high temperature, the colour of the material remains white (Figure 4D, Figure 4E and Figure 4F). Similar results were reported by Njoya and co-workers [8] on feldspars from Dschang-Cameroon, where the material was heated between $1050^{\circ} \mathrm{C}$ and $1300^{\circ} \mathrm{C}$ and no change in colour was observed. As with the feldspars from Foumban (this study), only the morphology of the cones is modified. The high concentration of alkalis in LTMB causes the material to carbonize at $1200^{\circ} \mathrm{C}$ (Figure 4C) to a black mass. The intensity of this colour is proportional to the quantity of ferromagnesium minerals present in the rock and to the rate of temperature increase during firing. Therefore, the origin of a material has an influence on its properties and the quality of the results obtained [3]. Sample LTMB is more viscous than sample LTP because of the presence of high amounts of $\mathrm{CaO}(2.02 \%)$ in LTMB than in LTP $(0.78 \%)$. LTMB has a fixed melting temperature at $1100^{\circ} \mathrm{C}$ and LTP melts in the range $1050^{\circ} \mathrm{C}-1100^{\circ} \mathrm{C}$. The high fusibility of these materials is due to the presence of $\mathrm{Na}_{2} \mathrm{O}$ and $\mathrm{K}_{2} \mathrm{O}$ fluxing agents found in the alkaline feldspars (around 85\% modal). This high fusibility also depends on the low percentages of ferromagnesian minerals which is higher in LTMB than in LTP. Higher concentrations of $\mathrm{Na}_{2} \mathrm{O} / \mathrm{K}_{2} \mathrm{O}$ to lower concentrations of ferromagnesian minerals results to a decrease in the temperature at which the glassy phase occurs.

Similarities to the results obtained in this study have been reported by Elimbi et al. [5]. They worked on three Cameroonian feldspathic materials, namely syenites from Lala (Mont Koupé), nepheline syenites from Eboundja (Kribi) and granitic pegmatite from Penja. These similarities are observed both in terms of the mineral compositions and fusibility tests. They obtained albite, alkaline feldspar (microcline), quartz, plagioclase (albite and bytownite) and amphiboles as the main mineral phases. They found from the fusibility tests that on the cones of particles from one material to another, the vitreous phases start to form from $1100^{\circ} \mathrm{C}$ just as observed for sample LTP. The pegmatite from Penja remains white at $1150^{\circ} \mathrm{C}$ (as with LTP in our case) but the vitreous phase occurs at a slightly lower temperature $\left(1100^{\circ} \mathrm{C}\right)$. Just as with the nepheline syenite of Eboundja and the syenite of Lala, sample LTMB turned brown at $1100^{\circ} \mathrm{C}$.

\section{Conclusion}

This study focused on the characterization of feldspathic materials from Foum- 
ban for their potential as ceramic fluxes. The results of the mineralogical and petrographic analyses show that the rock consists of alkaline feldspars (orthoclase and microcline) and plagioclase (albite). From a geochemical point of view, the samples have a fairly high alkaline content $\left(\mathrm{K}_{2} \mathrm{O} / \mathrm{Na}_{2} \mathrm{O}\right.$ and $\left.\mathrm{Al}_{2} \mathrm{O}_{3}\right)$. However, these rocks also have a high $\mathrm{Fe}_{2} \mathrm{O}_{3}$ and $\mathrm{TiO}_{2}$ content which imparts a dull colour in the fired products. Fusibility tests carried out on samples having the highest amount of alkali showed that, the temperature at which the vitreous phase occurs is $1100^{\circ} \mathrm{C}$ for LTMB and varies between $1050^{\circ} \mathrm{C}-1100^{\circ} \mathrm{C}$ for LTP. This finding is in accordance with the result of the alkali content of the samples. The variation in the colours of the powders during heat treatment shows that LTP remains white while LTMB turns brown, due to the presence of ferromagnesian minerals (amphibole, biotite, pyroxene) which contain $\mathrm{Fe}_{2} \mathrm{O}_{3}$ and $\mathrm{TiO}_{2}$ in large quantities in LTMB. These materials could well be used as fluxing additives for ceramics.

\section{Conflicts of Interest}

The authors declare no conflicts of interest regarding the publication of this paper.

\section{References}

[1] Gougazeh, M., Bamousa, A. and Hasan, A. (2018) Evaluation of Granitic Rocks as Feldspar Source: Al Madinah, Western Part of Saudi Arabia. Journal of Taibah University for Science, 12, 21-36. https://doi.org/10.1080/16583655.2018.1451111

[2] Dondi, M. (2018) Feldspathic Fluxes for Ceramics: Sources, Production Trends and Technological Value. Resources, Conservation \& Recycling, 133, 191-205. https://doi.org/10.1016/j.resconrec.2018.02.027

[3] Arib, A., Sarhiri, A., Moussa, R., Remmal, T. and Gomina, M. (2007) Caractéristiques structurales et mécaniques de céramiques à base d'argiles: Influence de la source de feldspath. Comptes Rendus Chimie, 10, 502-510. https://doi.org/10.1016/j.crci.2006.01.005

[4] Ismail, A.I.M., et al. (2018) Exploring Syenites from Ring Complexes in the Eastern Desert (Egypt) as Ceramic Raw Materials. Periodico di Mineralogia, 87, 67-81.

[5] Elimbi, A., Lamilen, D.B., Melo, U.C. and Njopwouc, D. (2005) Caractérisation chimico-minéralogique et comportement thermique de trois matériaux feldspathiques camerounais utilisables comme fondants en céramique, silicate industriel. Silicate Industriel, 70, 167-175.

[6] Elimbi, A., Dika, J.M. and Djangang, C.N. (2014) Effects of Alkaline Additives on the Thermal Behavior and Properties of Cameroonian Poorly Fluxing Clay Ceramics. Journal of Minerals and Materials Characterization and Engineering, 2, 484-501. https://doi.org/10.4236/jmmce.2014.25049

[7] Tchakounte Bakop, T., Tene Fongang, R.T., Melo, U.C., Kamseu, E., Miselli, P. and Leonelli, C. (2013) Sintering Behaviors of Two Porcelainized Stoneware Compositions Using Pegmatite and Nepheline Syenite Minerals. Journal of Thermal Analysis and Calorimetry, 114, 113-123. https://doi.org/10.1007/s10973-012-2890-5

[8] Njoya, D., et al. (2010) Chemical and Mineralogical Characterization and Ceramic Suitability of Raw Feldspathic Materials from Dschang (Cameroon). Bulletin of the 
Chemical Society of Ethiopia, 24, 39-46. https://doi.org/10.4314/bcse.v24i1.52959

[9] Bomeni, I.Y., et al. (2018) Ceramic with Potential Application of Ngwenfon Alluvial Clays (Noun, West Cameroon) in Building Construction: Mineralogy, Physicochemical Composition and Thermal Behaviour. Construction and Building Materials, 182, 493-503. https://doi.org/10.1016/j.conbuildmat.2018.06.135

[10] Nkalih, A.M., Pilate, P., Yongue, R.F., Njoya, A. and Fagel, N. (2018) Suitability of Foumban Clays (West Cameroon) for Production of Bricks and Tiles. Journal of Minerals and Materials Characterization and Engineering, 6, 244-256. https://doi.org/10.4236/jmmce.2018.62018

[11] Mefire, A.N., et al. (2018) Mineralogy and Geochemical Features of Foumban Clay Deposits (West Cameroon): Genesis and Potential Applications. Clay Minerals, 53, 431-445. https://doi.org/10.1180/clm.2018.31

[12] Njoya, A., et al. (2006) Genesis of Mayouom Kaolin Deposit (Western Cameroon). Applied Clay Science, 32, 125-140. https://doi.org/10.1016/j.clay.2005.11.005

[13] Weecksteen, G. (1957) Carte géologique de reconnaissance du Cameroun à l'échelle 1/500 000. Levés effectués de 1949 à 1956. Notice explicative sur la feuille Douala-Est. Imp. Nat. Yaoundé.

[14] Dias, F.G., Segadães, A.M., Perottoni, C.A. and Cruz, R.C.D. (2017) Assessment of the Fluxing Potential of Igneous Rocks in the Traditional Ceramics Industry. $\mathrm{Ce}$ ramics International, 43, 16149-16158. https://doi.org/10.1016/j.ceramint.2017.08.190

[15] U.S. Departement of Agriculture (1975) Munsell Soil Color Charts Quoted in Part from U.S. Departement of Agriculture Handbook, Soil Manuel. Baltimore.

[16] Bayraktar, Ç.O. (2002) Qualify Feldspar Production at Çire Akmaden. International Ceramics Journal, 8, 35-38.

[17] Izquierdo, P.M., Andrade, Couce, M.L., Bao, I.M. and Marcet, P. (1997) Miramontes Obtention of Feldspar Raw Material for Porcelain and Ceramic Industries from Biotite-Porphyryritic Granite (Porrino Granite). Silicates Industriels, 62, 97-104.

[18] Pouliquen, M. (2010) Les feldspaths. Fiche détaillées lasim, 7 p. https://www.lasim.org >doc_gratuite

[19] Bishadi, M.A., Mostafa, M.Z. and Mamoun, M. (2000) Properties and Grindability of Egyptian Red-Sea Feldspar for Ceramic Industries. Tile \& Brick International, 16, 238-245.

[20] Silva, J.C., Ulsen, C., Bergerman, M.G. and Horta, D.G. (2019) Reduction of $\mathrm{Fe}_{2} \mathrm{O}_{3}$ Content of Foyaite by Flotation and Magnetic Separation for Ceramics Production. Journal of Materials Research and Technology, 8, 4915-4923. https://doi.org/10.1016/j.jmrt.2019.06.017

[21] Amarante, M.A., de Sousa, A.B. and Leite, M.M. (1997) Beneficiation of a Feldspar Ore for Application in the Ceramic Industry. Journal-South African Institute of Mining and Metallurgy, 97, 193-196.

[22] Saklar, S., Oktay, C. and Karadeniz, M. (2004) Beneficiation of Feldspar from Yozgat Region Granites. Key Engineering Materials, 264-268, 1419-1422. https://doi.org/10.4028/www.scientific.net/KEM.264-268.1419 